\title{
Zamyšlení nad dokumentem \\ Mezinárodní teologické komise \\ Hedání univerzální etiky: nový pohled na přirozený zákon
}

CTIRAD VÁCLAV POSPÍŠIL

Domnívat se, že lze jen několika slovy obsáhnout vše, co přináší chronologicky zatím poslední a více než stostránkový dokument Mezinárodní teologické komise věnovaný problematice přirozeného zákona, by bylo opravdu bláhové. Ze skrupulózního převyprávění hutného textu by navíc nevyhnutelně čišela nudnost, tak typická pro každou prezentaci, která nemá tak říkajíc svou vlastní „duši“. Pojmeme-li však následující příspěvek především jako pozvání k pozorné četbě, ba analýze zmíněného dokumentu, jehož česká verze již prochází recenzním řízením, a jako další pobídku k reflexi nad dotyčnou tematikou, pak se takový přístup jeví být přijatelný jak pro autora, tak, doufejme, i pro adresáty těchto řádků.

Platí-li, že cíl je první v řádu uvažování a poslední v řádu promítání záměru do života, pak je třeba vzhledem k avizovanému textu v první řadě podtrhnout, že naše další lidsky důstojná existence $\mathbf{v}$ tomto světě nutně vyžaduje vypracování jakési univerzální etiky (srov. čl. 116). Tuto finalitu by měl bez problémů akceptovat každý normálně uvažující a čestný člověk.

Základní problém věřícího, který chce o dané záležitosti hovořit se všemi, tedy i s vyznavači mimokřestanských náboženství a s lidmi bez vyznání, tkví v tom, že plnost lidství, a tím pádem i přirozeného zákona se zjevuje až v Ježíši Kristu (srov. čl. 115). Porozumění tomu, co je pravé lidství obnovené v Kristu, je možné jedině díky daru Ducha svatého (srov. např. 1 Kor 12,3; čl. 110-112). Na jedné straně tedy nemůžeme nepracovat na poli etiky, která staví na přirozeném rozumu, obecně platných lidských principech a přínosech současné vědy, a to jednak proto, abychom mohli usilovat o onu univerzální etiku, jednak proto, abychom tímto zpo̊sobem odpovědně působili ve prospěch pozemské obce na rovině takzvaného přirozeného práva (srov. 4. kapitola, čl. 83-100), což pochopitelně úzce souvisí se sociální naukou a praxí církve. Na druhé straně se tím ovšem vystavujeme nemalému riziku, že budeme přinejmenším implicitně dávat stranou Ježíše Krista jako Spasitele všech lidí a jako stvořitelského základu především každé z lidských bytostí.

Absolutizoval-li by křestanský myslitel takovýto přístup k etice, vyvstávala by otázka, zda by to vlastně neimplikovalo tezi, podle níž by Ježíš Kristus byl pouze jedním z mnoha paralelních projevů transcendence či Boha v dějinách náboženství, což je typické pro takzvaný pluralistický směr v oblasti teologie mimokřestanských náboženství. Je ovšem evidentní, že zdravě uvažující křestan tuto myšlenkovou linii musí odmítnout, nebot' se příčí základní pravdě jeho víry, totiž pravdě o vtělení jednoho z Trojice, pravdě o soupodstatnosti Syna s Otcem. 
Z druhé strany vzato ale platí, že milost přirozenost nepohlcuje (srov. čl. 101) stejně jako Kristovo božství nepohlcuje jeho lidství. Z řečeného vyplývá, že jednostranné opomíjení onoho racionálního a přirozeného základu etiky $\mathrm{v}$ křestanské morálce by zase nevyhnutelně směřovalo $\mathrm{k}$ myšlenkovému schématu, které by vykazovalo podobnosti s monofyzitismem.

Na poměr mezi přirozeností a nadpřirozeností (milostí) je tudíž třeba aplikovat onen myšlenkový vzorec, s nímž se setkáváme $\mathbf{v}$ chalkedonském dogmatu, tedy rozlišovat, ale neoddělovat a nesměšovat. Mezi milostí a přirozeností existuje perichoretický poměr, vždyt' osoba Slova je v naší přirozenosti a naše lidská přirozenost je zase $\mathrm{v}$ osobě Slova. Toto vzájemné prostupování pochopitelně neznamená pohlcení. Křestanský morální teolog by proto mèl svoji práci dělat jaksi nadvakrát. Jednou by měl docházet k plnému poznání pravdy ohledně člověka a jeho pravé důstojnosti v Kristu a v Duchu svatém na základě světla víry (srov. GS, čl. 22). Ve druhé části svého snažení by se měl pokoušet sdělovat tuto svou jistotu tak, aby byla pokud možno srozumitelná, nakolik je to jenom možné, i nevěřícímu člověku, a to na základě filosofie, racionality a současné vědeckosti. Jestliže platí, že cílem morálky je dosažení posledního cíle člověka, a jestliže tento cíl spočívá v dokonalém spodobení s Kristem, pak také cesta vedoucí k tomuto cíli musí vykazovat podobnost s Kristem. Právě proto křestanská morálka musí mít dvě rozlišitelné a zároveň neoddělené roviny, které strukturálnè odpovídají dvěma přirozenostem vtěleného Božího Syna. Právě nastíněný princip se snadno vyslovuje, s jeho uváděním do praxe je to ale pochopitelně mnohem obtížnější.

Hovoříme-li o přirozeném zákoně, nemůžeme se vyhnout otázce: Co je vlastně lidská přirozenost? Právě nastolené otázce je $\mathrm{v}$ prezentovaném dokumentu věnována celá třetí kapitola (srov. čl. 69-82). Pochopitelně se zde setkáváme se všemi základními historickými peripetiemi a kontroverzemi ohledně chápání lidské přirozenosti. $\mathrm{V}$ dané souvislosti je třeba podotknout, že christologická reflexe dnes věnuje velkou pozornost pojmu „osoba“, nepoměrně menší prostor bývá věnován otázce přirozenosti. Je tudíž nabíledni, že christolog $\mathrm{v}$ prezentovaném dokumentu nalezne nejednu cennou inspiraci.

Zdá se být vhodné podotknout, že MTK již v dokumentu Vybrané otázky $z$ christologie (1979, čl. 1.3.2.4) upozorňovala na problémy s užíváním výrazu „přirozenost“ v současném kulturním kontextu. Je evidentní, že koncilní otcové shromáždění v roce 451 v Chalkedonu nemínili a ani nemohli kanonizovat určitou filosofii (srov. MTK, Vybrané otázky z christologie, čl. 3.2.5). Apofatický moment dogmatické definice tkví také $\mathrm{v}$ tom, že magisterium použije určitý termín $\mathrm{v}$ jeho obecné či předfilosofické poloze a vztáhne ho k nevýslovnému mystériu. Daný výraz tak dostane v novém, transcendentním kontextu dřive netušenou významovou konotaci, a tak nejenom něco odhaluje, ale zároveň nechává mnoho zahaleného. Tím se zárovně ponechává otevřená cesta $\mathrm{k}$ dalším novočtením, která přinesou přiští epochy $\mathrm{v}$ dějinách teologie. Nezapomínejme, že vypovídací hodnota dogmatu má vzhledem k transcendentnímu významu vektorickou povahu, dogmata ukazují správný smèr, který má 
člověka přivádět $\mathrm{k}$ poslednímu cíli, $\mathrm{k}$ blaženému patření. Hovoříme-li o lidské prrirozenosti, pak to platí v první řadě o chalkedonském dogmatu, který hovoří o lidské přirozenosti vtěleného Božího Syna, a následně o lidské př̀irozenosti jako takové. Ačkoli dokument o přirozeném zákoně necituje právě připomenutý text MTK z roku 1979, v tom, co jsme právě konstatovali, můžeme vidèt jednu ze základních charakteristik, která proniká celým dokumentem o přirozeném zákoně, kde se dozvídáme, že lidská přirozenost nám ještě určitě není v každém ohledu známa, i ona se přece jeví jako tajemství.

Narůstá-li naše poznání ohledně lidství, pak se nesmíme divit tomu, že vnímání a chápání zákona vepsaného do této přirozenosti se $\mathrm{v}$ určitých ohledech $\mathrm{v}$ dějinách proměňuje. Přirozený zákon tudíž není vyjádřitelný jednou provždy a definitivně. Zdá se, že lidská přirozenost jako mystérium transcenduje jednotlivá vyjádření přirozeného zákona, která jsou historicky i kulturně podmíněná, a proto vyjevují tento přirozený zákon $\mathrm{v}$ zásadě analogicky:

„Jedná se o mravní zákon vepsaný do srdce lidí, což si lidstvo stále jasnèji uvědomuje v souvislosti s tím, jak postupuje vpřed dějinami. Výraz tohoto přirozeného zákona rozhodně není statickou záležitostí, nejedná se o nějaký seznam definitivních a neměnných předpisů. Přirozený zákon je spíše pramen inspirace, který stále prýští, když se hledá objektivní základ určité univerzální etiky“ (čl. 113).

Právě uvedená myšlenka je opravdu osvobozující, nebot́ evidentně představuje deideologizaci pojmu přirozeného zákona jako něčeho statického a jednou provždy daného. Nezapomínejme na to, že sama lidská přirozenost má dynamickou povahu a je povolána k ustavičnému sebepřekračování, což je jedna z jejích základních charakteristik. Nejsme tudíž pod diktátem jednoho konkrétního zpracování tematiky přirozeného zákona, nýbrž jsme postaveni před sebe samotné jako před otázku a výzvu.

Přirozený zákon tudíž nemá vzhledem $\mathrm{k}$ člověku heteronomní povahu (srov. čl. 10,43, 75), protože věrnost takto pojímanému zákonu je $\mathrm{v}$ zásadě věrností sobě samotnému. Zároveň se ale nejedná ani o prostou a jednostrannou autonomii, nebot zákon přirozenosti pochází od Dárce naší existence.

Na tomto místě si dovolím vyslovit určitou kritiku na adresu práce MTK, která nevěnuje pozornost svým předchozím dokumentům a ve svých chronologicky pozdějších textech předchozí výsledky své práce $\mathbf{v}$ zásadě necituje. Otázkou heteronomie a autonomie se totiž ve svých tezích o křestanské morálce, které byly schváleny MTK na obecné rovině a vydány jako součást jednoho z jejích dokumentů, zabýval již na počátku sedmdesátých let minulého století Hans Urs von Balthasar (srov. MTK, Krestanská morálka a jeji normy 9 tezi H. Urs von Balthasara, dokument z roku 1974). Zmíněný autor dospívá k závěru, že jedině v Ježiši Kristu dochází k překonání disharmonie mezi heteronomií a autonomií. Svůj výklad staví především na skutečnosti, že Ježíš je jak jedno s Otcem, tak člověk.

K tomu si dovolím poznamenat, že k témuž závěru dospíváme, když analyzujeme Kristovu synovskou poslušnost, která jednak není vztažena k ně- 
jakému zprostředkování, nýbrž představuje napodobování Otce, jenž je pro Syna tím jediným př́kazem (srov. Jan 5,19 ), jednak je rovněž věrností sobě samému, nebot Boží vůle je $\mathrm{v}$ imanentní Trojici pouze jediná, a proto společná Otci, Synu a Duchu svatému. Lidská vůle Kristova tedy svým podřizováním se Otcovè vůli zároveň naplňuje věrnost vlastní osobě vtěleného Slova. Právě na tomto základě pak platí, že ten, kdo následuje Ježíše Krista, dokonalého člověka, se tím samým stává více člověkem, více sám sebou (srov. GS, čl. 22).

Platí tudíž, že to, co není autenticky lidské, nemůže být autenticky křestanské. Mezi autentickou lidskostí a kristovským základem naší nové existence $\mathbf{v}$ Duchu svatém tedy existuje pomèr hermeneutického kruhu. Kristus nám zjevuje velikost a pravou důstojnost lidství, autentické lidství je zase průvodním znakem a základním prvkem věrohodnosti našeho svědectví v tomto světě.

Dále bychom si měli jasně uvědomovat, že alternativa autonomie - heteronomie je ve skutečnosti falešná. Čirá, ba prométheovská autonomie člověka ve vztahu k Bohu je iluzí, nebot naše vlastní identita je darovaná od druhého, a proto pravá věrnost sobě je zároveň věrností Stvořiteli. Pochopitelně nesprávné je také to, když se vše redukuje na čirou heteronomii, na naplňování litery zákona bez hlubšího porozumění a souznění, což vede k ne př́íliš vábnému legalismu. Striktní heteronomie je rovněž projevem nedospèlosti, proto také mojžíšovský zákon můžeme chápat jako vychovatele v době nezralosti, v Kristu jsme ale povoláni k tomu, abychom opustili stav dětství a stali se ve vztahu k Otci zralými muži a ženami. Dialogický charakter trojičního tajemství, který je základním předpokladem naší existence povolané k dialogu s Otcem v Synu neseném obdarováním Ducha svatého, nás přivádí k poznání, že autonomie je smysluplná jedině tehdy, když je harmonicky spjatá s heteronomií. Monologická autonomie je sebeklamem subjektu, který se chce ustavit jako absolutní a soběstačný, a tak podléhá klamnému sebezbožnění, což ho ale jednak uvězňuje v sobè, jednak uvádí do bytostného rozporu se sebou samým, nebot mé Já je nevysvětlitelné bez božského otcovského Ty.

Vratme se ale k dokumentu o přirozeném zákoně. V článku 116 čteme:

„Když nabízíme náš příspěvek k procesu hledání určité univerzální etiky a když předkládáme její základ, který je racionálně ospravedlnitelný, rádi bychom vyzvali odborníky a mluvčí velkých náboženských, sapienciálních i filosofických tradic lidstva, aby podnikli podobnou práci jako my vycházeje při tom z pramenů, aby se nakonec dospělo ke společnému uznání univerzálních mravních norem, jež by se zakládaly na rozumovém přístupu k realitě. Tato práce je nezbytná a naléhavá.“

S touto finalitou souvisí především první kapitola dokumentu, která nám staví před oči různé přístupy $\mathrm{k}$ problematice přirozeného zákona ve velkých náboženských a sapienciálních tradicích lidstva včetně křestanství (srov. čl. 12-35). Dokument je tedy nejenom podnětem k zamyšlení nad daným té- 
matem, ale také výzvou k mnohostrannému dialogu. Ukazuje se také, že takzvané „zlaté pravidlo,“ podle něhož se máme vůči bližnímu chovat tak, jak chceme, aby se druzí chovali k nám, je obsaženo v různých výrazových podobách prakticky ve všech zkoumaných tradicích!

Jako překladatel tohoto dokumentu jsem nechtěl zůstat k dané výzvě lhostejný, a proto jsem se obrátil na kolegy z oblasti pravoslavné teologie, teologické školy CČSH a judaistiky, s nimiž se setkávám především na půdě HTF UK, předal jsem jim pracovní verzi překladu a poprosil je, zda by se mohli z hlediska své konfesní a náboženské tradice $\mathrm{k}$ tomuto textu vyslovit. Pokud oslovení dostojí svému slibu, měly by se jejich příspěvky objevit na stránkách periodika Teologické texty. Reflexe nad tímto vskutku velmi aktuálním a opravdu naléhavým tématem tak bude, jak pevně doufám, pokračovat i na rovině ekumenického a mezináboženského dialogu. I tímto způsobem se totiž tajuplně projevuje a nenápadně uskutečňuje tajemství církve, která je přece svátostí jednoty celého lidského rodu. 